\title{
PENGARUH LATIHAN SKIPPING DAN SIDE HOP TERHADAP KETERAMPILAN DRIBBLING PADA ANAK DIDIK U16-17 SSB PSDM KABUPATEN BLITAR
}

\author{
Ririd Tsalis Mutaqin \\ Eko Hariyanto \\ I Nengah Sudjana \\ Fakultas IImu Keolahragaan Universitas Negeri Malang \\ E-mail: tsalisririd87@gmail.com
}

\begin{abstract}
Many elements that affect the mastery of dribbling skills, such as agility and speed. Agility and dribbling speed can be improved by skipping plyometrics workout and side hop. The aimed of this study was to determine the effect of skipping exercise and hop side of the soccer player dribbling skills U16-17 in SSB PSDM Blitar. This research method using quasi-experimental research design. This quasi-experimental design used in two groups of subjects namely the skipping and side hop with the conventional group. The dribbling test were used as a research instrument. The data analysis technique used is the analysis of variants (one-way ANOVA). The subjects were soccer player U16-17 SSB PSDM totaling 24 players. Results from this study have been analyzed by using analysis of variance (one-way ANOVA) with significance level of 0.05 . Of the test obtained crieteria $(F) 7,30>4,30$ on results posstest skipping and side hop group, then for the conventional group obtained criteria (F) $0.16<4.30$ for difference between groups and skipping and side hop with a conventional group acquired criteria $(F)$ amounted to $23.32>4.30$. The conclusion of the research is, skipping exercise and side hop gives a better effect than conventional exercise to increase soccer player dribbling skills U16-17 SSB PSDM Blitar.
\end{abstract}

Key words: experiment, skipping and side hop, dribbling

\begin{abstract}
Abstrak: Menggiring bola merupakan salah satu teknik dasar sepakbola yang wajib dikuasai oleh semua pemain sepakbola. Banyak unsur yang mempengaruhi penguasaan keterampilan dribbling, seperti kelincahan dan kecepatan. Kelincahan dan kecepatan menggiring bola dapat ditingkatkan dengan latihan pliometrik skipping dan side hop. Tujuan dari penelitian ini adalah untuk mengetahui pengaruh latihan skipping dan side hop terhadap keterampilan menggiring bola pemain sepakbola U16-17 di SSB PSDM Kabupaten Blitar. Metode penelitian ini menggunakan rancangan penelitian eksperimen semu. Rancangan eksperimen semu ini digunakan pada dua kelompok subjek yaitu kelompok skipping dan side hop dengan kelompok konvensional. Intrumen yang digunakan dalam penelitian ini adalah dribbling. Teknik analisis data yang digunakan adalah analisis varian satu jalur (one way anova). Subjek penelitian ini adalah pemain sepakbola U16-17 SSB PSDM Kabupaten Blitar yang berjumlah 24 pemain. Hasil dari penelitian ini yang telah dianalisis dengan menggunakan teknik analisis varian satu jalur(one way anova) dengan taraf signifikansi 0,05. Dari uji tersebut diperoleh Fhitung sebesar 7,30 > 4,30 Ftabel pada hasil posstest kelompok skipping dan side hop, kemudian untuk kelompok konvensional diperoleh Fhitung sebesar 0,16 4,30 dan untuk selisih kelompok skipping dan side hop dengan kelompok konvensional diperoleh Fhitung sebesar 23,32 > 4,30 Ftabel. Kesimpulan dari hasil penelitian yang telah dilakukan, latihan skipping dan side hop memberikan pengaruh yang lebih baik dibandingkan latihan konvensional terhadap peningkatan keterampilan menggiring bola pemain sepakbola U16-17 SSB PSDM Kabupaten Blitar.
\end{abstract}

Kata kunci: eksperimen, skipping dan side hop, menggiring bola 


\section{GELANGGANG PENDIDIKAN JASMANI INDONESIA}

Kajian Teori, Praktik Pendidikan dan Pembelajaran Volume 1, Nomor 1, Tahun 2017

Sepakbola merupakan suatu olahraga permainan yang sudah dimainkan sejak lama di berbagai Negara. Sepakbola lahir dengan berbagai istilah yang berbeda. Namun semua permainan itu memiliki tujuan yang sama, yaitu permainan yang dimainkan oleh dua tim dan pemain dari tiap tim berusaha memainkan bola, menjaga bola agar tidak direbut oleh tim lawan dan berusaha memasukkan bola ke dalam gawang lawan. Menurut Batty (2004:8) Sepakbola adalah permainan beregu yang dimainkan oleh individu-individu untuk menyebarluaskan gagasan dari pelatih agar sepakbola menjadi permainan yang lebih baik dan menyerang dalam kerangka suatu kerjasama beregu.

Permainan sepakbola di Indonesia telah menjadi olahraga yang sangat digemari. Olahraga ini sudah menjadi olahraga wajib bagi semua kalangan masyarakat, baik kalangan dewasa sampai anak-anak memainkan permainan ini. Sepakbola dapat dilakukan atau dimainkan di berbagai tempat, mulai dari sekitar rumah, di tingkat sekolah, jalanan, hingga yang dimainkan secara professional. Pertandingan sepakbola dilaku-kan dalam waktu $2 \times 45$ menit dan waktu istirahat pertengahan babak 15 menit. Jika kedudukan sama imbang, maka diadakan perpanjangan waktu selama 2x15 menit, hingga didapat pemenang, namun jika sama kuat maka diadakan adu penalti. Wasit dapat menentukan berapa waktu tambahan di setiap akhir babak sebagai pengganti dari waktu yang hilang akibat pergantian pemain, cedera yang membutuhkan pertolongan, ataupun penghentian lainnya. Waktu tambahan ini disebut sebagai injury time.

Wasit memberikan kartu kuning apabila pemain melakukan pelanggaran yang cukup keras maka wasit dapat memberikan peringatan dengan kartu kuning atau kartu merah. Kartu kuning merupakan peringatan atas pelanggaran seperti bersikap tidak sportif, secara terus-menerus melanggar peraturan, sedangkan pemain yang mendapatkan kartu merah harus keluar dari pertandingan tanpa bisa digantikan dengan pemain lainnya. Beberapa contoh tindakan yang dapat diganjar kartu merah adalah pelanggaran berat yang membahayakan atau menyebabkan cedera parah pada lawan. Lapangan sepakbola internasional yang digunakan memiliki panjang yang berkisar antara 100-110 meter dan lebar 6475 meter. Di bagian tengah kedua ujung lapangan, terdapat area gawang yang berupa persegi empat berukuran dengan lebar 7,32 meter dan tinggi 2,48 meter. Di bagian depan dari gawang terdapat area pinalti yang berjarak 16,5 meter dari gawang. Area ini merupakan batas seorang kiper boleh menangkap bola dengan tangan dan menentukan kapan sebuah pelanggaran mendapatkan hadiah tendangan penalti atau tidak (Luxbacher, 2004:1).

Permainan sepakbola pada masa saat ini telah mengalami perkembangan yang pesat. Permainan ini telah menjadi industri yang sangat menjanjikan. Banyak berdiri klub-klub profesional yang nantinya klub-klub pro-fesional tersebut mencari bakat pemain sejak usia dini. Hal tersebut dibarengi dengan banyak berdirinya sekolah-sekolah sepakbola yang bertujuan mencetak bibit pemain berkualitas yang nantinya akan dapat bermain untuk klub professional. Dalam permainan sepakbola setiap pemain berusaha mencetak gol dengan cara melakukan operan (passing), menggiring (dribbling), menembak (shooting). Selain cara-cara tersebut, ada cara lain yang bisa dilakukan oleh para pemain yang tidak membawa bola, seperti bergerak mencari ruang kosong, membantu dan melindungi pemain yang sedang membawa bola. Menurut Sucipto (2000:17) beberapa teknik dasar yang perlu dimiliki pemain sepakbola, yaitu menendang (kicking), menghentikan (stoping), menggiring (dribbling), menyundul (heading), merampas (tackling), lemparan ke dalam (throw-in), dan menjaga gawang (goal keeper). Seorang pemain sepakbola tidak hanya harus berteknik baik, tetapi faktorfaktor seperti fisik, taktik dan mental yang dilatih secara maksimal sangat berpengaruh untuk meraih suatu prestasi.

Untuk meningkatkan kemampuan dan penguasaan gerak tubuh dengan bola dalam sepakbola harus memiliki tujuh kelengkapan pokok yaitu (1) Teknik dasar, (2) kelenturan dan kelincahan mengendalikan bola, (3) olah gerak cepat dengan bola, (4) membawa bola tanpa memandang ke arahnya, (5) gerak tipu dengan bola, (6) kreativitas dan 
improvisasi, (7) teknik menendang dan menerima bola (Coerver, 1985:19).

Semua teknik dasar tersebut harus dikua-sai dengan baik oleh seorang pemain sepak-bola. Seorang pemain sepakbola tidak hanya harus berteknik baik, tetapi faktor-faktor seperti fisik, taktik dan mental yang dilatih secara maksimal sangat berpengaruh untuk meraih suatu prestasi. Salah satu teknik dasar yang penting dalam permainan sepakbola adalah teknik dasar dribbling. Dribbling adalah mengolah bola dengan bola tetap pada penguasaan kita. Mielke (2007:1) "dribbling adalah keterampilan dasar dalam sepakbola karena semua pemain harus mampu meguasai bola saat sedang bergerak, berdiri, atau bersiap melakukan operan atau tembakan". Scheuneman (2005:47) menjelaskan bahwa "memiliki skill menggiring bola memang penting, tapi pe-main hendaknya tidak lupa bahwa meng-giring bola sangat menguras tenaga dan seringkali memperlambat tempo per-mainan".

Menggiring bola menurut Mielke (2007:2) bahwa ada beberapa prinsip yang harus diperhatikan antara lain: 1) Menggiring bola dekat kaki, 2) Menggiring bola dengan sisi luar bagian depan kaki sementara pinggul tetap mengarah lurus ke depan, 3) Pemain berlatih mengubah arah menggiring bola, menambah atau mengurangi kecepatan dalam menggiring bola dan sewaktuwaktu menghentikan bola. Pada hakikatnya meng-giring bola (dribbling) dapat dilakukan dengan tiga cara, yakni: 1) Menggiring bola dengan kaki bagian dalam, 2) Menggiring bola dengan kaki bagian luar, 3) Menggiring bola dengan punggung kaki (Mielke 2007:25).

Menggiring menggunakan sisi kaki bagian dalam merupakan teknik pertama yang dapat dipelajari. Menggiring menggunakan sisi bagian dalam memungkinkan seorang pemain untuk menggunakan sebagian besar permukaan kaki sehingga kontrol terhadap bola akan semakin besar. Walaupun menggiring menggunakan kaki bagian dalam sedikit mengurangi kecepatan, namun akan memberikan perlindungan bola yang lebih baik dari sergapan lawan. Sentuhlah bola dengan sisi kaki bagian dalam dan posisikan kakimu secara tegak lurus dengan bola. Tendanglah dengan pelan untuk memper-tahankan kontrol bola dan pusatkan kekuatan tendangan pada bagian tengah bola sehingga memudahkanmu mengontrol arahnya. Ketika melakukan dribbling dengan kaki bagian dalam, usahakan bola tetap berdekatan dengan kakimu. Jarak langkahmu adalah jarak di antara kedua kaki ketika kamu berlari secara normal. Jika perlu, kamu selalu bisa mempercepat langkah, tetapi jangan sampai kehilangan kontrol terhadap bolanya (Mielke, 2007:2). Menggiring menggunakan sisi kaki bagian luar biasanya digunakan ketika pemain yang menguasai bola sedang berlari dan mendorong bola sehingga bisa mempertahankan bola tersebut tetap berada di sisi luar kaki. Secara umum, keterampilan ini digunakan ketika seorang pemain mencoba mengubah arah atau bersiap untuk mengoper bola ke teman satu timnya (Mielke, 2007:4). Kura-kura kaki merupakan bagian sepatu tempat tali sepatu berada, bisa memberikan kekuatan dan kontrol. Kura-kura kaki atau bagian punggung sepatu digunakan sebagai bidang tendangan utama untuk melakukan dribbling bila kamu ingin bergerak cepat di lapangan. Kele-bihan dari menggiring menggunakan kura-kura kaki adalah dapat memberikan permukaan yang datar pada bola dan juga dapat membuat bola bergerak berbelok dan menukik (Mielke, 2007:5).

Penguasaan keterampilan teknik dasar dribbling harus dikuasai sejak usia dini, karena teknik ini merupakan teknik yang dasar bagi seorang pemain untuk dapat bermain sepakbola dengan baik. Selain teknik dasar yang harus dikuasai, ada aspek lain untuk menunjang pemain dalam menguasai keterampilan teknik dasar dribbling yaitu dengan latihan. Latihan dilakukan untuk menunjang penguasaan keterampilan teknik dasar yang lebih baik. Latihan dapat dilakukan di dalam atau di luar lapangan. Pada sebuah sekolah sepakbola keterampilan dasar dribbling yang diberikan terkadang masih kurang karena waktu yang terbatas. Seorang pelatih hanya memberikan teknik dan gerakan, pada kenyataannya masih banyak unsur yang mempengaruhi penguasaan keterampilan dribbling, seperti kelincahan dan kecepatan. Kelincahan dalam dribbling sangatlah penting, jika dribbling dilakukan dengan kelincahan maka seorang pemain dapat melewati pemain 
Ririd Tsalis Mutaqin, Pengaruh Latihan Skipping dan Side Hop terhadap Keterampilan Dribbling Sepakbola Pada Anak Didik U16-17 SSB PSDM Kabupaten Blitar

lawan dengan mudah. Jika seorang pemain sepakbola memiliki teknik menggiring bola yang baik, maka pemain tersebut dapat bermain dengan baik dalam suatu permainan sepakbola. Ketika pemain telah menguasai kemampuan dribbling secara efektif, sumbangan mereka di dalam pertandingan akan sangat besar (Mielke, 2007:1). Apabila pemain hanya mendapatkan latihan yang diberikan pelatih saja, keterampilan dribbling pemain akan masih kurang.

Menurut Budiwanto (2012:16), latihan adalah "proses melakukan kegiatan olahraga yang dilakukan berdasarkan program latihan yang disusun secara sistematis". Untuk memperoleh keterampilan dribbling yang baik, seorang pemain memerlukan latihan yang intensitas, frekuensi banyak dan sistematis. Harsono (1988:2) pengertian latihan adalah sesuatu proses berlatih yang sistematis yang dilakukan secara berulangulang, dan yang kian hari jumlah beban latihannya kian bertambah. Suharno (1998 :5) menjelaskan bahwa latihan adalah suatu proses penyempurnaan kualitas atlet secara sadar untuk mencapai prestasi yang maksimal dengan diberi beban fisik dan mental secara teratur, terarah, bertahap, meningkat dan berulang-ulang waktunya. Budiwanto (2012:16) mengemukakan bahwa "latihan adalah proses melakukan kegiatan olahraga yang dilakukan berdasarkan program latihan yang disusun secara sistematis, bertujuan untuk meningkatkan kemampuan atlet dalam upaya mencapai prestasi yang semaksimal mungkin, terutama dilaksanakan untuk persiapan menghadapi suatu pertandingan".

Prinsip-prinsip latihan menurut Budiwanto (2012: 16) meliputi prinsip beban bertambah (overload), prinsip spesialisasi (speciali-zation), prinsip perorangan (individualization), prinsip variasi (variety), prinsip beban meningkat bertahap (progressive increase of load), prinsip perkembangan multilateral (multilateral development), prinsip pulih asal (recovery), prinsip reversibilitas (reversibility), menghindari beban latihan berlebih (overtraining), prinsip melampaui batas latihan (the abuse of training), prinsip aktif partisipasi dalam latihan, dan prinsip proses latihan menggunakan model. Prinsipprinsip latihan menurut Budiwanto (2012: 16) meliputi: (1) Prinsip beban lebih (overload), prinsip beban lebih adalah prinsip latihan yang menekankan pada pembebanan latihan yang lebih berat daripada yang mampu dilakukan oleh atlet (Hadisasmita dan Syarifuddin, 1997:131). Konsep latihan dengan beban lebih berkaitan dengan intensitas latihan. Beban latihan pada suatu waktu harus merupakan beban lebih dari sebelumnya. Hal tersebut bertujuanagar sistem fisiologis dapat menyesuaikan dengan tuntutan fungsi yang dibutuhkan untuk meningkatkan kemampuan yang lebih tinggi. Apabila tubuh sudah mampu mengadaptasi beban latihan yang diberikan, maka beban berikutnya harus ditingkatkan secara bertahap (Sukadiyanto, 2011:18-19). (2) Prinsip spesialisasi (specialization), spesialisasi berarti mencurahkan segala kemampuan, baik fisik maupun psikis pada satu cabang tertentu (Harsono, 1988:109). Prinsip spesialisasi adalah latihan yang khusus atau untuk satu cabang olahraga tertentu dimana latihan tersebut mempunyai pengaruh khusus untuk sistem fisiologis tertentu yang mendapat beban lebih pada kelompok otot yang digunakan. Setiap bentuk latihan yang dilakukan oleh olahragawan memiliki tujuan yang khusus (Sukadiyanto, 2011:19). Prinsip perorangan (individualization). Dalam meres-pon beban latihan untuk setiap olahragawan tentu akan berbeda-beda, sehingga beban latihan bagi setiap orang tidak dapat disamakan antara orang yang satu dengan lainnya (Sukadiyanto, 2011:15). Sedangkan menurut Harsono (1988:112) "tidak ada dua orang yang sama persis, dan tidak ada pula dua orang yang secara fisiologis maupun psikologis sama". Setiap orang mempunyai perbedaan individu masing-masing. Demikian pula, setiap atlet berbeda dalam kemampuan, potensi, dan karakteristik belajarnya. Faktor-faktor seperti umur, jenis kelamin, bentuk tubuh, kedewasaan, latar belakang pendidikan, lamanya berlatih, tingkat kesegaran jasmaninya, ciri-ciri psikologisnya, semua harus ikut dipertimbangkan dalam mendesain program latihan bagi atlet. (3) Prinsip variasi (variety). Program latihan yang baik harus disusun secara variatif untuk menghindari kejenuhan, keengganan dan keresahan yang merupakan kelelahan secara psikologis (Sukadiyanto, 2011:20). Prinsip latihan variasi adalah bentuk latihan yang berbagai macam atau bervariasi yang 
bertujuan untuk menghindari rasa bosan karena latihan yang monoton. Variasi-variasi latihan yang dikreasikan dan diterapkan secara baik akan dapat menjaga fisik maupun mental atlet, sehingga rasa bosan dapat dihindari (Harsono, 1988:121). (4) Prinsip beban meningkat bertahap (progresif). Latihan bersifat progresif, artinya dalam pelaksanaan latihan dilakukan dari yang mudah ke yang sukar, sederhana ke kompleks, umum ke khusus, bagian ke keseluruhan, ringan ke berat, dan dari kuantitas, serta dilaksanakan secara ajeg, maju dan berkelanjutan (Sukadiyanto, 2011:19). Sedangkan menurut Budiwanto (2012:22) "Prinsip latihan secara progresif menekankan bahwa atlet harus menambah waktu latihan secara progresif dalam keseluruhan program latihan".Prinsip latihan secara progresif menekankan bahwa atlet harus menambah waktu latihan secara progresif dalam keseluruhan program latihan. Prinsip latihan ini dilaksanakan setelah proses latihan berjalan menjelang pertandingan. Peningkatan latihan harus dimulai dari tingkat dasar atau pemula ke tingkat yang lebih tinggi, dan dibarengi dengan peningkatan beban latihan. (5) Prinsip partisipasi aktif dalam latihan. Bahwa pemahaman yang jelas dan teliti ada tiga faktor, yaitu lingkup dan tujuan latihan, kebebasan dan peran kreatif atlet. Tugastugas selama tahap persiapan adalah penting sebagai pertimbangan prinsip-prinsip tersebut.

Partisipasi aktif tidak terbatas hanya pada waktu latihan. Seorang atlet akan melakukan kegiatan meski tidak di bawah pengawasan dan perhatian pelatih. Selama waktu bebas, atlet dapat melakukan pekerjaan, dalam aktivitas sosial yang memberikan kepuasaan dan ketenangan, tetapi dia tentu harus istirahat yang cukup. Ini tentu akan harus memperbaharui fisik dan psikologis untuk latihan berikutnya. Jika atlet tidak seksama mengamati semua kebutuhan latihan yang tidak terawasi, dia jangan diharapkan dapat melakukan pada tingkat maksimumnya (Budiwanto, 2012:20). (6) Prinsip perkem-bangan multilateral. Pada cabang olahraga, pengembangan multilateral, atau pengem-bangan fisik secara keseluruhan adalah necesityatau satu kesatuan. Menurut Bompa (1994:38) menya- takan bahwa "jika prinsip ini diterapkan, fase latihan multilateral akan menguntungkan untuk mengembangkan ke-mampuan atlet secara fisik dan psikologis yang merupakan dasar maksimalisasi kinerja atlet pada pengembangan karirnya". (7) Prinsip pulih asal (recovery). Pada waktu menyusun program latihan yang menyeluruh, harus mencamtumkan waktu pemulihan yang cukup. Apabila tidak memperhatikan waktu pemulihan ini, maka atlet akan mengalami kelelahan yang luar biasa dan berakibat pada sangat menurunnya penampilan. Atlet akan mengalami kelelahan hebat (overtraining) dan berakibat penurunan penampilan, apabila tidak memperhatikan waktu pemulihan (Budiwanto, 2012: 26). Bompa (1994:118) mengemukakan bahwa "pemulihan adalah sebuah proses multifaktor yang membu-tuhkan pelatih dan atlet untuk memahami penampilan fisiologis atlet, efek fisiologis dari kepelatihan dan intervensi pemulihan, dan efek mengintegrasikan pelatihan dan strategi pemulihan".

Sukadiyanto (2011:7) menambahkan ciri-ciri latihan sebagai berikut. (1) Suatu proses untuk mencapai tingkat kemampuan yang lebih baik dalam berolahraga, yang memer-lukan waktu tertentu (pertahapan), serta memerlukan perencanaan yang tepat dan cermat, (2) Proses latihan harus dilakukan secara ajeg, maju dan berkelanjutan (kon-tinyu). Sedang bersifat progresif maksudnya materi latihan yang diberikan dari yang mudah ke yang sukar, dari yang sederhana ke yang lebih sulit (kompleks), dan dari yang ringan ke yang lebih berat, (3) pada setiap satu kali tatap muka (satu sesi/satu unit latihan) harus memiliki tujuan dan sasaran, (4) materi latihan harus berisikan materi, teori dan praktek, agar pemahaman dan penguasaan keterampilan menjadi relatif permanen, (5) menggunakan metode ter-tentu, yaitu cara paling efektif yang direncanakan secara bertahap dengan memperhitungkan faktor kesulitan, komplek-sitas gerak, dan penekanan pada sasaran latihan. Latihan merupakan sesuatu yang penting bagi seorang pemain sepakbola. Latihan dilakukan secara sistematis dengan jumlah beban yang terus bertambah yang bertujuan untuk meningkatkan kemampuan seorang pemain agar mencapai prestasi maksimal. 
Ririd Tsalis Mutaqin, Pengaruh Latihan Skipping dan Side Hop terhadap Keterampilan Dribbling Sepakbola Pada

Menurut Scheunemann (2012:11) materi latihan sepakbola seperti " (1) Fisik, (2) teknik, (3) taktik, (4) mental, (5) set piece, (6) Formasi, (7) teknik bagi penjaga gawang yang diberikan pada pemain setiap sesi latihan".

Selain harus memilki latihan yang baik dan sistematis, seorang olahragawan harus memiliki kondisi fisik yang baik dalam usaha peningkatan kemampuan. Kondisi fisik merupakan satu prasyarat yang sangat diperlukan dalam setiap usaha peningkatan prestasi seorang atlet, bahkan dapat dikatakan dasar landasan titik tolak suatu awalan olahraga prestasi. Kondisi Fisik adalah satu kesatuan utuh dari komponenkomponen yang tidak dapat dipisahkan. Artinya bahwa setiap usaha peningkatan kondisi fisik, maka harus mengembangkan semua komponen tersebut (Sajoto, 1988:57).

Komponen-komponen kondisi fisik menurut Sajoto (1988:58-59): (1) Kekuatan (strenght). Kekuatan adalah komponen kondisi fisik yang menyangkut masalah kemampuan seseorang atlet pada saat mempergunakan otot-ototnya, menerima beban dalam waktu kerja tertentu. Macammacam latihan kekuatan dapat dilakukan sebagai berikut, (a) latihan dengan menggunakan berat badan sendiri, (b) latihan menggunakan beban yang diangkat, ditarik, didorong, atau ditahan, (c) latihan bermain dengan menggunkana alat-alat yang diberi beban, (d) latihan menggunakan alat yang spesifik (Budiwanto, 2012:35). (2) Daya tahan (endurance). Daya tahan adalah keadaan atau kondisi tubuh yang mampu untuk bekerja untuk waktu yang lama, tanpa mengalami kelelahan yang berlebihan setelah menyelesaikan pekerjaan tersebut (Harsono, 1988:155). Daya tahan dibedakan menjadi dua golongan, masing-masing adalah: (a) Daya tahan otot setempat, adalah kemampuan seseorang dalam mempergunakan suatu kelompok ototnya, untuk berkontraksi terus menerus dalam waktu relatif cukup lama, dengan beban tertentu. Daya tahan otot adalah daya tahan sekelompok otot besar berupa gerakan berulang-ulang selama tiga menit atau lebih tetapi biasanya lebih dari lima menit (Mutohir, 2007:55). (b) Daya tahan umum, adalah kemampuan seseorang dalam mempergunakan sistem jantung, pernafasan dan peredaran darahnya secara efektif dan efisien dalam menjalankan kerja terus menerus. Daya tahan umum adalah kemampuan tubuh untuk melakukan aktivitas terus-menerus dalam waktu lama (lebih dari 10 menitdengan aerobic predominant energy system (Mutohir, 2007:54). (3) Daya ledak otot. Daya ledak adalah kemampuan seseorang untuk melakukan kekuatan maksimum, dengan usahanya yang dikerahkan dalam waktu sependekpendeknya. Daya ledak merupakan kemampuan untuk melakukan aktivitas secara tibatiba dan cepat dengan mengerahkan seluruh kekuatan dalam waktu yang singkat (Mutohir, 2007:55). (4) Kecepatan. Kecepatan adalah kemampuan seseorang dalam melakukan gerakan berkesinam-bungan, dalam bentuk yang sama dalam waktu sesingkat-singkatnya. Komponen kecepatan erat sekali kaitannya dengan komponen kekuatan, kelincahan, koordinasi dan daya tahan (Mutohir, 2007:55). Kecepatan adalah kemampuan seseorang dalam melakukan gerakan berkesinambungan, dalam bentuk yang sama dalam waktu sesingkatsingkatnya (Sajoto, 1988:58). (5) Kelentukan. Kelentukan adalah keefektifan seseorang dalam penyesuaian dirinya untuk melakukan segala aktivitas tubuh dengan penguluran seluas-luasnya, terutama otototot dan ligamen-ligamen disekitar persendian. Menurut Budiwanto (2012:40) "kelentukan adalah kemampuan untuk dapat menggerakkan bagian atau anggota badan dengan luas gerak tertentu pada suatu sendi". (6) Keseimbangan. Keseimbangan adalah kemampuan seseorang mengendalikan organ-organ syaraf ototnya selama melakukan gerak-gerak yang cepat, dengan perubahan letak titik-titik berat badan yang cepat pula baik dalam keadaan statis maupun lebih-lebih dalam gerak dinamik. Menurut Mutohir (2007:56) "komponen keseimbangan terdiri atas: (a) keseimbangan static dimana tubuh dalam kedaan diam, (b) keseimbangan dinamik dimana tubuh berada dalam posisi bergerak". (7) Koordinasi. Koordinasi adalah kemampuan seseorang dalam mengintegrasikan gerakan yang berbeda kedalam suatu pola gerakan tunggal secara efektif. Koordinasi adalah berhubungan dengan kemampuan untuk menggunakan panca indra seperti penglihatan dan pendengaran, bersama-sama 
dengan tubuh tertentu di dalam melakukan kegiatan motorik dengan harmonis dan ketepatan tinggi (Harsuki, 2003:274). Koordinasi adalah kemampuan seseorang, dalam mengintegrasikan gerakan yang berbeda ke dalam suatu pola gerakan tunggal secara efektif (Sajoto, 1988:59). (8) Kelincahan. Kelincahan adalah kemampuan seseorang dalam merubah arah dalam posisi-posisi di arena tertentu. Seorang yang mampu merubah satu posisi kesuatu posisi yang berbeda dengan kecepatan tinggi dan koordinasi gerak yang baik, berarti kelincahannya cukup tinggi. Menurut Mutohir (2007:56) "kelincahan adalah kemampuan tubuh atau bagian tubuh untuk mengubah arah gerakan secara mendadak dalam kecepatan yang tinggi". Kelincahan adalah kemampuan seseorang dalam mengubah arah, dalam posisi-posisi di arena tertentu (Sajoto, 1988:59). (9) Ketepatan. Ketepatan adalah kemampuan seseorang dalam mengendalikan gerak-gerak bebas terhadap suatu sasaran. Menurut Mutohir (2007:56) "ketepatan adalah kemampuan tubuh untuk mengendalikan gerakan bebas menuju suatu sasaran pada jarak tertentu". (10) Reaksi. Reaksi adalah kemampuan seseorang segera bertindak secepatnya dalam menanggapi rangsangan-rangsangan yang datang lewat indera, syaraf atau feeling lainnya. Reaksi merupakan kemampuan tubuh untuk melakukan aktivitas kinetis secepatnya begitu rangsangan terhadap reseptor terjadi (Mutohir, 2007:56).

Kondisi fisik sangat diperlukan dalam usaha peningkatan prestasi keterampilan menggiring bola. Karena menggiring bola sangatlah menguras tenaga. Pemberian latihan harus melihat kesesuaian dengan kebutuhan dan kemampuan pemain. Hal itu bertujuan untuk menghindari adanya kelelahan psikis dan beban lebih. Anak didik SSB PSDM Kabupaten Blitar berusia 16-17 tahun termasuk dalam kelompok remaja awal.

Rentang usia remaja dapat dibagi menjadi dua bagian, yaitu usia 12 atau 13 tahun sampai dengan 17 atau 18 tahun adalah remaja awal, dan usia 17 atau 18 tahun sampai dengan 21 atau 22 tahun adalah remaja akhir". Masa remaja berlangsung antara umur 12 tahun sampai dengan 21 tahun bagi wanita dan 13 tahun sampai dengn 22 tahun bagi pria. Pada usia tersebut remaja mulai belajar untuk hidup mandiri, mulai adanya peningkatan yang terjadi secara cepat, serta perubahan pada kondisi fisik (Mappiare dalam Ali dan Asrori, 2010:9).

Banyak faktor yang mempengaruhi peru-bahan fisik selama remaja. Perubahan tersebut dibagi dua yaitu perubahan eksternal dan perubahan internal. Yang dimaksud dengan perubahan eksternal adalah perubahan yang terjadi dan dapat dilihat pada fisik luar anak. Perubahan internal adalah perubahan yang terjadi dalam organ dalam tubuh remaja dan tidak tampak dari luar (Rahayu, 2006:264).

Pertama ciri-ciri perubahan eksternal meliputi: tinggi badan, berat badan, proporsi tubuh, organ seks, dan ciri-ciri seks sekunder. Tinggi badan, rata-rata anak perempuan mencapai tinggi matang pada usia tujuh belas tahun dan delapan belas tahun, sedangkan anak laki-laki mencapai tinggi matang pada usia setahun setelah perempuan. Proporsi tubuh, terbentuknya bagianbagian tubuh seseorang menjadi lebih lebar atau lebih panjang yang dapat menimbulkan ketidak idealan badan seseorang.

Pertumbuhan yang terjadi sebagai perubahan individu lebih mengacu dan menekankan pada aspek perubahan fisik ke arah lebih maju. Dengan kata lain, pertumbuhan usia remaja dapat di definisikan sebagai proses perubahan fisiologis yang bersifat progresif dan kontinyu serta berlangsung dalam periode tertentu. Sebagai hasil dari pertumbuhan adalah bertambahnya berat, panjang atau tinggi badan, tulang dan otototot menjadi lebih kuat, lingkar tubuh menjadi lebih besar, dan organ tubuh menjadi lebih sempurna (Ali dan Asrori, 2010:11).

Teori golden age atau usia emas di berbagai cabang olahraga biasanya berada pada rentang usia 14-25 tahun. Untuk mencapai prestasi yang maksimal dalam rentang waktu golden age perlu adanya pola pembinaan yang terukur dan terstruktur dengan program yang tepat dan pembinaan jangka panjang yang sesuai.

Dengan latihan yang baik dan sistematis dan peningkatan kondisi fisik yang porsinya sesuai dengan perkembangan usia remaja, diharapkan terjadi peningkatan prestasi 
Ririd Tsalis Mutaqin, Pengaruh Latihan Skipping dan Side Hop terhadap Keterampilan Dribbling Sepakbola Pada Anak Didik U16-17 SSB PSDM Kabupaten Blitar

seorang atlet kearah yang lebih baik. Banyak model latihan yang dapat mendukung keterampilan dribbling, antara lain latihan pliometrik skipping dan side hop. Latihan plyoometrics memungkinkan otot untuk mencapai maksimal dalam waktu sesingkat mungkin (Chu, 2006:10). Pliometrik adalah suatu metode untuk mengembangkan daya ledak (explosive power), suatu komponen penting dari sebagian besar prestasi atau kinerja olahraga. Latihan pliometrik adalah salah satu bentuk materi latihan yang diberikan pelatih kepada atletnya yang tujuannya untuk meningkatkan daya ledak otot. Pliometrik memberikan dampak yang signifikan terhadap kekuatan otot yang hasilnya dapat memberikan hasil kecepatan dan kelincahan yang baik. Manfaat pliometrik menurut Chu (2006:15) "(1) peningkatan kekuatan otot, (2) peningkatan kekuatan daya ledak, (3) peningkatan kekuatan tulang (4), peningkatan keseimbangan, (5) meningkatkan kelincahan, (6) peningkatan kecepatan, (7) resistensi terhadap cedera, (8) peningkatan kinerja olahraga". Latihan pliometrik telah digunakan sebagai metode latihan terutama untuk mengembangkan kekuatan, kecepatan dan power (Redcliffe dan Farentinos, 1985:2). Kekuatan, kecepatan dan power adalah serangkaian komponen fisik yang sangat penting dalam berbagai cabang olahraga.

Latihan pliometrik dapat dilakukan dalam bentuk latihan skipping dan side hop. Gerakan pliometrik dirancang untuk menggerakkan otot pinggul dan tungkai. Pliometrik Side hop merupakan model latihan yang pas untuk melatih keterampilan dribbling. Side hop merupakan suatu bentuk latihan melompat menggunakan satu atau dua kaki. Latihan side hop adalah suatu bentuk latihan yang bertujuan meningkatkan daya ledak otot secara eksplosif. Latihan side hop relevan dengan karakteristik permainan sepakbola yang mayoritas menggunakan kekuatan kaki. Lakukan lompatan dengan cepat sehingga gerakan yang dilakukan bersifat ekplosif ini tentunya akan sangat baik untuk perkembangan daya ledak otot tungkai yang hendak dilatih. Latihan side hop lompatannya adalah ke arah samping melewati kerucut, sehingga pemain akan melakukan lompatan yang tinggi dan semaksimal mungkin untuk melewati kerucut. Pada saat latihan side hop tanpa disadari pemain melakukan gerakan menggunakan power yang besar dan kuat.

Langkah-langkah dalam melakukan latihan side hop menurut Chu (1998:95) adalah (1) Menjaga kaki selebar bahu, (2) melompati setiap cones, (3) mendarat dengan kedua kaki dalam waktu yang sama, (4) ayunkan kedua lengan untuk mempercepat gerakan. Mielke (2007:4) menyatakan "latihan yang baik untuk mempersiapkanmu melakukan dribbling menggunakan sisi kaki bagian luar adalah melangkah ke samping atau ke depan". Hal itu sesuai dengan pengertian latihan side hop yaitu latihan melompat ke samping. Latihan side hop sangat tepat diterapkan dalam program latihan dribbling sepakbola. Latihan side hop merupakan bentuk latihan pliometrik yang dapat meningkatkan unsur kelincahan dan kecepatan yang dibutuhkan dalam keterampilan dribbling sepakbola.

Sedangkan lompat tali menurut Solihin (2010:90) adalah serangkaian gerakan melompati tali dengan menggunakan tumpuan satu atau dua kaki dan mendarat dengan dua kaki yang dilakukan secara berulang-ulang. Skipping merupakan suatu bentuk latihan dengan menggunakan tali dan meloncatinya secara terus-menerus.

Lompat tali adalah jenis latihan kardio yang pantas digunakan untuk siapa saja dan dimana saja. Lompat tali hanya membutuhkan seseorang dan tali lompat, selain itu lompat tali lebih murah bila dibandingkan dengan peralatan olahraga lainnya dan latihannya menyenangkan. Manfaat dari skipping: membakar lemak (mengurangi berat badan dan juga menjaga berat badan), stamina (daya tahan), koordinasi (kemampuan gerak), kelincahan, dan pergerakan (Aagard, 2012:3). Latihan skipping sangat cocok untuk melatih seorang pemain sepakbola untuk menguasai keterampilan dribbling, karena skipping dapat meningkatkan kelincahan. Menurut Scheunemann (2012:17) "kelincahan adalah kemampuan pemain merubah arah dan kecepatan baik saat mengolah bola maupun saat melakukan pergerakan tanpa bola". Berdasarkan definisi tersebut, dapat disimpulkan bahwa kelincahan merupakan suatu hal yang penting dalam teknik dribbling bola. Pemain dalam menggiring bola membutuhkan kelincahan untuk berlari dan merubah arah. Latihan 
skipping yang baik dilakukan secara bertahap dengan beban yang terus bertambah.

Berdasarkan latar belakang yang ada, peneliti ingin mengetahui apakah ada Pengaruh Latihan Skipping dan Side Hop Terhadap Keterampilan Dribbling Sepakbola pada Anak Didik U16-17 SSB PSDM Kabupaten Blitar.

Tujuan dari penelitian ini adalah untuk mengetahui pengaruh latihan skipping dan side hop terhadap keterampilan menggiring bola pemain sepakbola U16-17 di SSB PSDM Kabupaten Blitar.

\section{METODE}

Berkaitan dengan penelitian ini, maka penelitian yang dilakukan menggunakan rancangan penelitian eksperimen berupa "rancangan kelompok kontrol pratespaskates berpasangan (matching pretestposttest control group design)" (Sukmadinata, 2013:207).

Rancangan penelitian menggunakan Pretest-Posttest Design dilakukan dengan cara kelompok dilakukan pengukuran prates terlebih dahulu sebelum dikenai perlakuan. Langkah selanjutnya kelompok tersebut dikenai perlakuan tertentu dengan membagi dua kelompok. Penelitian eksperimen adalah penelitian yang mengamati pengaruh perlakuan terhadap suatu perilaku yang ditimbulkan dari perlakuan yang akan diberi.

Penelitian ini bertujuan untuk mengetahui bagaimana pengaruh bentuk latihan pening-katan keterampilan dribbling yaitu latihan skipping dan side hop yang akan diberikan pada anak U16-17 SSB PSDM Kabupaten Blitar. Tujuan dari penelitian eksperimental menjelaskan perbandingan pengaruh antara sebelum diberi perlakuan dan sesudah diberikan perlakuan terhadap prestasi keterampilan dribbling. Penelitian ini dilaksa-nakan untuk meningkatkan prestasi keteram-pilan dribbling dengan memberikan bentuk latihan skipping dan side hop agar kelin-cahan dan kecepatan dribbling meningkat. Bentuk latihan ini membandingkan dua bentuk latihan agar kelincahan dan kece-patan meningkat sehingga prestasi dribbling anak didik U1617 SSB PSDM Kabupaten Blitar meningkat. Variabel yang diteliti berupa peningkatan prestasi keterampilan dribbling sebagai variabel terikat dan latihan skipping dan side hop sebagai variabel bebas.

Penelitian ini berjalan 6 minggu dan dilakukan tiap minggunya selama 3 kali. Menurut M. Sajoto (1988:48) tentang frekuensi dan lama latihan selama 3 kali setiap minggu agar tidak terjadi kelelahan kronis, adapun lama latihan yang diperlukan adalah 6 minggu atau lebih. Tahapan penelitian yang dilakukan dalam penelitian ini adalah sebagai berikut: (1) Tes menggiring bola sebelum diberi perlakuan yang disebut pretest (2) Pembagian kelompok eksperimen dan kelompok kontrol dengan menggunakan teknik matching pairing (3) Pemberian perlakuan berupa program latihan skipping dan side hop pada kelompok eksperimen seperti yang telah ditentukan dan latihan konvensional untuk kelompok kontrol, latihan diberikan selama 6 minggu, dengan frekuensi latihan 3 kali dalam 1 minggu dengan jumlah latihan 18 kali pertemuan. (4) Setelah selesai diberi perlakuan selama 16 kali pertemuan untuk kelompok eksperimen berupa latihan skipping dan side hop dan kelompok kontrol berupa latihan konvensional diadakan posttest untuk mengetahui kemampuan dribbling bola setelah diberikan perlakuan selama 6 minggu. (5) Data yang diperoleh selanjutnya dianalisis dengan teknik analisis yang digunakan.

Populasi dan sampel yang akan digunakan dalam penelitian ini adalah anak didik U16-U17 SSB PSDM Kabupaten Blitar. Menurut Winarno (2013:60) mengatakan bahwa "populasi dapat dinyatakan sebagai sekumpulan objek atau sumber penelitian". Populasi merupakan sekumpulan dari objek yang akan diteliti. Sedangkan sampel adalah bagian dari populasi yang akan diteliti. Menurut Winarno (2013:60) mengatakan bahwa "sampel adalah bagian dari populasi atau sejumlah anggota populasi yang mewakili karakterisktik populasi itu". Sampel merupakan objek bagian dari populasi yang mewakili karakteristik populasi tersebut yang akan diteliti.

Arikunto (2010:173) menjelaskan bahwa "populasi adalah keseluruhan subjek penelitian". Populasi dari penelitian ini adalah pemain sepakbola di SSB PSDM U16-U17 Kabupaten Blitar yang berjumlah 24 pemain. 
Ririd Tsalis Mutaqin, Pengaruh Latihan Skipping dan Side Hop terhadap Keterampilan Dribbling Sepakbola Pada Anak Didik U16-17 SSB PSDM Kabupaten Blitar

Sedangkan pembagian kelompok untuk kelompok eksperimen dan kelompok kontrol menggunakan teknik ordinal pairing matching.

Pembagian kelompok eksperimen diambil dari skor yang didapat pemain ketika melakulan pretest. Jumlah sampel 24 orang anak didik melakukan pretest keterampilan dribbling, kemudian pembagian kelompok dilakukan dengan cara pairing matching. Pemain yang memiliki nilai dribbling yang sama dipasangkan/dijodohkan, satu masuk kelompok eksperimen, satu masuk kelompok konvensional. Kelompok eksperimen terdiri dari 12 sampel pemain dan kelompok skipping dan side hop juga terdiri dari 12 sampel pemain. Anak didik yang akan diteliti di tes kemampuan menggiring bola terlebih dahulu untuk mengetahui data awal sampel. Langkah berikutnya kelompok diberi perlakuan. Setelah diberi perlakuan bentuk latihan yang telah ditetapkan kemudian anak didik di tes kembali (posttest) untuk mengetahui apakah ada pengaruh peningkatan prestasi keterampilan dribbling setelah diberikan bentuk latihan tersebut.

Instrumen dalam pengumpulan data pretest dan posttest menggunakan observasi dan tes. Pada tahap awal pretest, peneliti melakukan observasi selama 2 minggu untuk melihat kemapuan objek yang akan diteliti, setelah itu dilakukan pretest. Instrumen tes yang digunakan dalam penelitian ini adalah dengan menggunakan tes dribbling untuk mengukur keterampilan dribbling bola, (Hariyoko, 2010:349-351). yang mempunyai validitas tes sebesar 0,0661 dan realibitas tes sebesar 0,618. Pengumpulan data dalam penelitian ini berupa observasi, dokumentasi dan tes menggiring bola melewati rintangan. Teknik pengumpulan data menggunakan tes berbentuk tes keterampilan dribbling. Data yang diperoleh dari tes ini berupa angka sehingga dapat diolah untuk menarik kesimpulan peneliti. Teknik pengumpulan data dalam penelitian ini menggunakan 2 tahap yaitu, tahap persiapan dan tahap pelaksanaan.

Teknik analisis data yang digunakan dalam penelitian adalah analisis varian satu jalur yaitu untuk menguji perbedaan dua mean/rata-rata distribusi atau lebih. Dalam penelitian ini analisis yang digunakan menghendaki data berdistribusi normal dan homogen, sehingga dilakukan uji prasyarat. Data deskriptif dalam penelitian ini digunakan untuk analisis mean, median, nilai maksimal, nilai minimal dan standar deviasi dari hasil tes obyek.

Data kemampuan awal (pretest) peserta dianalisis untuk mengetahui kemampuan rata-rata keterampilan dribbling obyek sebelum dilakukan perlakuan. Data kemampuan akhir (posttest) peserta dianalisis untuk mengetahui perbedaan keterampilan dribbling setelah pemberian perlakuan. Sebelum dilakukan analisis varians satu jalur, terlebih dahulu harus dilakukan uji persyaratan yaitu berupa uji normalitas dan homogenitas. Prosedur analisis data dilakukan secara manual dengan menggunakan kalkulator.

Teknik yang digunakan untuk analisis uji normalitas data adalah teknik Liliefors. Uji normalitas ini digunakan untuk mengetahui apakah data yang diperoleh berdistribusi normal atau tidak. Uji normalitas pada penelitian ini menggunakan rumus pengujian normalitas dengan Z skor.

Uji homogenitas digunakan untuk menge-tahui apakah kedua sampel yang diambil mempunyai varian data yang sama atau tidak. Untuk mengetahui homogenitas dila-kukan dengan menggunakan uji $F$ (Sugiyono, 2013:175). Data yang dilakukan pengujian homogenitas adalah skor prestasi antara tes awal dari masing-masing kelompok dan skor prestasi anatara tes akhir dari masing-masing kelompok. Data dinya-takan homogen apabila $F$ dihitung $<F$ tabel, uji homogenitas ini digunakan taraf signifikan = 0,05 (Sugiyono, 2013:175). Pengujian hipotesis dengan menggunakan teknik analisis varians satu jalur dilakukan dengan taraf signifikasi $\alpha=0,05$. Teknik statistik analisis varians (Anava) satu jalur digunakan untuk menguji perbedaan dua mean kelompok atau sampel mandiri.

\section{HASIL}

Keseluruhan data yang diperoleh yaitu dari hasil tes awal (pretest) dan tes akhir (posttest) keterampilan dribbling para pemain SSB PSDM Kabupaten Blitar. Deskripsi data hasil tes dalam penelitian ini sebagai berikut.

Teknik yang digunakan untuk analisis uji normalitas data adalah teknik Liliefors. Uji 
normalitas ini digunakan untuk mengetahui apakah data yang diperoleh berdistribusi normal atau tidak. Uji normalitas pada penelitian ini menggunakan rumus pengujian normalitas dengan Z skor. Uji homogenitas digunakan untuk mengetahui apakah kedua sampel yang diambil mempunyai varian data yang sama atau tidak. Untuk mengetahui homogenitas dilakukan dengan menggunakan uji F

Tabel 1. Deskripsi Data Keterampilan Dribbling Pemain Sekolah Sepakbola PSDM Kabupaten Blitar.

\begin{tabular}{llcc}
\hline \multicolumn{2}{c}{ Data Prestasi } & $\begin{array}{c}\text { Tes } \\
\text { Awal }\end{array}$ & Tes Akhir \\
\hline \multirow{3}{*}{ Kelompok } & $\mathrm{N}$ & 12 & 12 \\
Latihan & Mean & 24,91 & 22,98 \\
Skipping \& & $\mathrm{SD}$ & 1,93 & 1,54 \\
side hop & Max & 28,99 & 26,05 \\
& Min & 22,47 & 21,12 \\
& $\mathrm{Jml}$ & 298,95 & 275,81 \\
\hline \multirow{4}{*}{ Kelompok } & $\mathrm{N}$ & 12 & 12 \\
Konvensional & Mean & 24,21 & 23,93 \\
& $\mathrm{SD}$ & 1,72 & 1,61 \\
& Max & 27,54 & 27,33 \\
& Min & 22,03 & 22,06 \\
& $\mathrm{Jml}$ & 290,53 & 287,25 \\
\hline
\end{tabular}

Data prestasi tes awal keterampilan dribbling kelompok latihan skipping \& side hop dengan rentangan skor antara 28,99 sampai dengan 22,47 , didapatkan rata-rata (mean) sebesar 24,91 simpangan baku (SD) sebesar 1,93, serta distribusi frekuensi sebagaimana ditunjukkan pada Tabel 1.

Tabel 2. Distribusi Frekuensi Prestasi Tes Awal Keterampilan Dribling Kelompok Latihan Skipping \& Side Hop.

\begin{tabular}{clcc}
\hline No & $\begin{array}{l}\text { Kelas } \\
\text { Interval }\end{array}$ & $\begin{array}{l}\text { Frekuensi } \\
\text { Absolut }\end{array}$ & $\begin{array}{l}\text { Frekuensi } \\
\text { Relatif }\end{array}$ \\
\hline 1 & $22,47-23,90$ & 5 & 41,66 \\
2 & $24,00-25,43$ & 3 & 25 \\
3 & $25,53-26,96$ & 2 & 16,66 \\
4 & $27,06-28,49$ & 1 & 8,33 \\
5 & $28,59-30,02$ & 1 & 8,33 \\
\hline & Jumlah & 12 & 100 \\
\hline
\end{tabular}

Berdasarkan tabel 2 dapat dilihat 7orang $(59,34 \%)$ memperoleh skor prestasi tes awal keterampilan dribbling di atas rata-rata, 5 orang $(41,66 \%)$ memperoleh skor prestasi tes awal keterampilan dribbling dibawah rata-rata.

Data prestasi tes akhir keterampilan dribbling kelompok latihan skipping dan side hop dengan rentangan skor antara 26,05 sampai dengan 21,12 , didapatkan rata-rata (mean) sebesar 22,98 simpangan baku (SD) sebesar 1,54, serta distribusi frekuensi sebagaimana ditunjukkan pada Tabel 3.

Tabel 3. Distribusi Frekuensi Prestasi Tes Akhir Keterampilan Dribbling Kelompok Latihan Skipping\& Side Hop.

\begin{tabular}{cccc}
\hline No & $\begin{array}{c}\text { Kelas } \\
\text { Interval }\end{array}$ & $\begin{array}{c}\text { Frekuensi } \\
\text { Absolut }\end{array}$ & $\begin{array}{c}\text { Frekuensi } \\
\text { Relatif }\end{array}$ \\
\hline 1 & $21,12-22,20$ & 4 & 33,33 \\
2 & $22,30-23,38$ & 5 & 41,66 \\
3 & $23,48-24,56$ & 1 & 8,33 \\
4 & $24,66-25,74$ & 1 & 8,33 \\
5 & $25,84-26,92$ & 1 & 8,33 \\
\hline & Jumlah & 12 & 100 \\
\hline
\end{tabular}

Berdasarkan tabel 3 dapat dilihat 8 orang $(66 \%)$ memperoleh skor prestasi tes awal keterampilan dribbling di atas rata-rata, 4 orang (34\%) memperoleh skor prestasi tes awal keterampilan dribbling dibawah ratarata.

Data prestasi tes awal Keterampilan Dribbling kelompok latihan konvensional dengan rentangan skor antara 27,54 sampai dengan 22,03, didapatkan rata-rata (mean) sebesar 24,21 simpangan baku (SD) sebesar 1,72 , serta distribusi frekuensi sebagaimana ditunjukkan pada Tabel 4.

Tabel 4. Distribusi Frekuensi Prestasi Tes Awal Dribbling Kelompok Latihan konvensional.

\begin{tabular}{cccc}
\hline No & Kelas Interval & $\begin{array}{c}\text { Frekuensi } \\
\text { Absolut }\end{array}$ & $\begin{array}{c}\text { Frekuensi } \\
\text { Relatif }\end{array}$ \\
\hline 1 & $22,03-23,24$ & 4 & 33,33 \\
2 & $23,34-24,55$ & 4 & 33,33 \\
3 & $24,65-25,86$ & 2 & 16,66 \\
4 & $25,96-27,17$ & 1 & 8,33 \\
5 & $27,27-28,48$ & 1 & 8,33 \\
\hline & Jumlah & 12 & 100 \\
\hline
\end{tabular}

Berdasarkan Tabel 4 dapat dilihat 6 orang (50\%) memperoleh skor prestasi tes awal keterampilan dribbling di atas rata-rata, 6 orang $(50 \%)$ memperoleh skor prestasi tes 
Ririd Tsalis Mutaqin, Pengaruh Latihan Skipping dan Side Hop terhadap Keterampilan Dribbling Sepakbola Pada

awal keterampilan dribbling dibawah ratarata.

Data prestasi tes akhir keterampilan Dribbling kelompok latihan konvensional dengan rentangan skor antara 27,33 sampai dengan 22,06, didapatkan rata-rata (mean) sebesar 23,93, simpangan baku (SD) sebesar 1,61, serta distribusi frekuensi sebagaimana ditunjukkan pada Tabel 5.

\begin{tabular}{cccc}
$\begin{array}{l}\text { Tabel } \\
\text { Akhir } \\
\text { Konvensional }\end{array}$ & $\begin{array}{c}\text { Distribusi } \\
\text { Dribbling }\end{array}$ & $\begin{array}{c}\text { Frekuensi } \\
\text { Kelompok }\end{array}$ & $\begin{array}{c}\text { Prestasi Tes } \\
\text { Latihan }\end{array}$ \\
\hline No & Kelas Interval & $\begin{array}{c}\text { Frekuensi } \\
\text { Absolut }\end{array}$ & $\begin{array}{c}\text { Frekuensi } \\
\text { Relatif }\end{array}$ \\
\hline 1 & $22,06-23,22$ & 4 & 33,33 \\
2 & $23,32-24,48$ & 5 & 41,66 \\
3 & $24,58-25,74$ & 1 & 8,33 \\
4 & $25,84-27,00$ & 1 & 8,33 \\
5 & $27,10-28,26$ & 1 & 8,33 \\
\hline \multicolumn{4}{c}{ Jumlah } \\
\hline
\end{tabular}

Berdasarkan Tabel 5 dapat dilihat 9 orang $(75 \%)$ memperoleh skor prestasi tes awal keterampilan dribbling di atas rata-rata, 3 orang (25\%) memperoleh skor prestasi tes awal keterampilan dribbling dibawah ratarata.

Untuk mengetahui normalitas data, uji normalitas dilakukan terhadap data skor prestasi dribbling masing-masing kelompok latihan dengan menggunakan uji Lilliefors pada taraf signifikansi $\alpha=0.05$. perhitungan lengkap uji normalitas dapat dilihat pada lampiran uji normalitas. Sedangkan rangkuman hasil perhitungannya ditunjukkan dalam tabel berikut ini.

Tabel 6. Rangkuman Hasil Uji Normalitas Skor Prestasi Tes Awal dan Tes Akhir Keterampilan Dribbling Masing-masing Kelompok Latihan.

\begin{tabular}{ccccc}
\hline Kelompok & $\mathbf{N}$ & $\mathbf{L}_{\text {hitung }}$ & $\mathbf{L}_{\text {tabel }}$ & Keterangan \\
\hline 1 & 12 & 0,02 & 0,242 & Normal \\
2 & 12 & 0,04 & 0,242 & Normal \\
3 & 12 & 0,03 & 0,242 & Normal \\
4 & 12 & 0,21 & 0,242 & Normal \\
\hline
\end{tabular}

Berdasarkan hasil perhitungan uji normalitas sebagaimana ditunjukkan dalam tabel 2 diperoleh harga $L$ hitung untuk seluruh kelompok latihan lebih kecil jika dibandingkan dengan $L$ tabel taraf signifikansi $\alpha=0.05$. Berarti dapat disimpulkan bahwa seluruh kelompok penelitian, data yang diperoleh dari hasil tes menunjukkan berdistribusi normal. Dengan demikian analisis data teknik analisis varian dapat dilanjutkan.

Uji homogenitas dilakukan terhadap data skor prestasi tes awal dengan tes akhir dribbling masing-masing kelompok latihan dengan menggunakan uji $F$ pada taraf signifikansi $\alpha=0,05$. Perhitungan lengkap uji homogenitas dapat dilihat pada lampiran uji homogenitas, sedangkan rangkuman hasil perhitungannya ditunjukkan dalam tabel berikut ini.

Tabel 7. Rangkuman Hasil Uji Homogenitas Skor Prestasi Tes Awal dan Tes Akhir Keterampilan Dribbling Masing-masing Kelompok Latihan.

\begin{tabular}{ccccc}
\hline Kel. & $\mathbf{N}$ & $\mathbf{F}_{\text {hitung }}$ & $\mathbf{F}_{\text {tabel }}$ & Keterangan \\
\hline 1 & 12 & 1,24 & 4,96 & Homogen \\
2 & 12 & 0,91 & 4,96 & Homogen \\
3 & 12 & 1,56 & 4,96 & Homogen \\
4 & 12 & 1,14 & 4,96 & Homogen \\
\hline
\end{tabular}

Berdasarkan hasil perhitungan uji homogenitas sebagaimana ditunjukkan dalam tabel 3 diperoleh harga $F$ hitung untuk seluruh kelompok latihan lebih kecil jika dibandingkan dengan $F$ tabel taraf signifikansi $\alpha=0.05$. Berarti dapat disimpulkan bahwa seluruh kelompok latihan berasal dari varian populasi yang homogen. Dengan demikian analisis data teknik analisis varian dapat dilanjutkan.

Setelah dilakukan uji persyaratan analisis varians, yaitu uji normalitas dan uji homogenitas dan didapatkan hasil bahwa seluruh kelompok latihan berasal dari populasi yang berdistribusi normal dan homogen. Selanjutnya akan dilakukan pengujian hipotesis dengan analisis varians (ANAVA) satu jalur. Pengujian hipotesis dengan analisis varians (ANAVA) satu jalur dilakukan terhadap data skor prestasi tes awal dengan tes akhir keterampilan dribbling kelompok latihan skipping \& side hop dengan menggunakan uji $F$ pada taraf signifikansi $\alpha=0,05$. Perhitungan lengkap pengujian hipotesis dengan analisis varians satu jalur dapat dilihat pada lampiran pengujian hipotesis analisis varian. Sedangkan rangkuman hasil perhitungannya ditunjukkan dalam tabel berikut ini. 
Tabel 8. Rangkuman Hasil Analisis Varians Skor Prestasi Kelompok Latihan Skipping \& Side Hop.

\begin{tabular}{ccccccc}
\hline $\mathbf{S V}$ & $\mathbf{D k}$ & $\mathbf{J K}$ & $\mathbf{V}$ & $\mathbf{F}_{\text {hitung }}$ & $\mathbf{F}_{\text {tabel }}$ & Keputusan \\
\hline $\mathrm{T}$ & $\begin{array}{r}24-1= \\
23\end{array}$ & 89,48 & - & & & \\
$\mathrm{A}$ & $2-1=1$ & 22,31 & 22,31 & 7,30 & 4.30 & $\mathrm{~F}_{\text {hitung }} \mathrm{F}_{\text {tabel }}(7,30>$ \\
& & & & & & \\
$\mathrm{D}$ & $\begin{array}{r}24-2 \\
22\end{array}$ & 67,17 & 3,05 & & &
\end{tabular}

Berdasarkan hasil perhitungan analisis varians sebagaimana ditunjukkan dalam tabel 4 diperoleh harga $F$ hitung untuk skor prestasi keterampilan Dribbling lebih besar jika dibandingkan dengan $F$ tabel taraf signifikansi $\alpha=0,05$. Dengan demikian dapat disimpulkan bahwa ada pengaruh yang signifikan prestasi keterampilan dribbling antara tes awal dengan tes akhir kelompok latihan skipping \& side hop.
Pengujian hipotesis dengan analisis varians (ANAVA) satu jalur dilakukan terhadap data skor prestasi tes awal dengan tes akhir keterampilan Dribbling kelompok latihan konvensional dengan menggunakan uji $F$ pada taraf signifikansi $\alpha=0,05$. Perhitungan lengkap pengujian hipotesis dengan analisis varians satu jalur dapat dilihat pada lampiran pengujian hipotesis analisis varians. Sedangkan rangkuman hasil perhitungannya ditunjukkan dalam Tabel berikut ini.

Tabel 9. Rangkuman Hasil Analisis Varians Skor Prestasi Kelompok Latihan konvensional.

\begin{tabular}{|c|c|c|c|c|c|c|}
\hline sv & Dk & JK & v & $F_{\text {hitung }}$ & $F_{\text {tabel }}$ & Keputusan \\
\hline T & $\begin{array}{c}24-1= \\
23\end{array}$ & 61,91 & - & & & \\
\hline A & $2-1=1$ & 0,44 & 0,44 & 0,16 & 4,30 & $F_{\text {hitung }}<F_{\text {tabel }}(0,16<4,30)$ \\
\hline D & $\begin{array}{r}24-2= \\
22\end{array}$ & 61,46 & 2,79 & & & \\
\hline
\end{tabular}

Berdasarkan hasil perhitungan analisis varians sebagaimana ditunjukkan dalam Tabel 5 diperoleh harga $F$ hitung untuk skor keterampilan dribbling lebih kecil jika dibandingkan dengan $\mathrm{F}$ tabel taraf signifikansi $\alpha=0,05$. Dengan demikian dapat disimpulkan bahwa tidak ada pengaruh yang signifikan prestasi keterampilan Dribbling antara tes awal dengan tes akhir kelompok latihan konvensional.

Pengujian hipotesis dengan analisis varians (ANAVA) satu jalur dilakukan terhadap selisih data skor prestasi tes awal dengan tes akhir keterampilan dribbling masing-masing kelompok latihan dengan menggunakan uji $F$ pada taraf signifikansi $\alpha=$ 0,05 . Perhitungan lengkap pengujian hipotesis dengan analisis varians satu jalur dapat dilihat pada lampiran pengujian hipotesis analisis varians. Sedangkan rangkuman hasil perhitungannya ditunjukkan dalam tabel berikut ini.

Tabel 10. Rangkuman Hasil Analisis Varians Selisih Skor Prestasi Tes Awal dengan Tes Akhir Masing-masing Kelompok Latihan.

\begin{tabular}{ccccccc}
\hline SV & Dk & JK & V & F hitung & F tabel & Keputusan \\
\hline $\mathrm{T}$ & $24-1=23$ & 31,93 & - & 23,32 & 4.30 & $\mathrm{~F}_{\text {hitung }} \mathrm{F}_{\text {tabel }}(23,32$ \\
\hline
\end{tabular}


Ririd Tsalis Mutaqin, Pengaruh Latihan Skipping dan Side Hop terhadap Keterampilan Dribbling Sepakbola Pada

\begin{tabular}{lrrrr}
\hline A & $2-1=1$ & 16,43 & 16,43 & $>4,30)$ \\
$\mathrm{D}$ & $24-2=22$ & 15,49 & 0,70 & \\
\hline
\end{tabular}

Berdasarkan hasil perhitungan analisis varians sebagaimana ditunjukkan dalam Tabel 6 diperoleh harga $F$ hitung untuk skor keterampilan dribbling lebih besar jika dibandingkan dengan $\mathrm{F}$ tabel taraf signifikansi $\alpha=0,05$. Dengan demikian dapat disimpulkan bahwa ada perbedaan pengaruh yang signifikan antara selisih prestasi keterampilan dribbling hasil latihan skipping \& side hop dengan latihan konvensional.

\section{PEMBAHASAN}

Berdasarkan hasil pengujian hipotesis antara latihan skipping \& side hop dengan latihan konvensional dalam peningkatan prestasi keterampilan dribbling, latihan skipping \& side hop memberikan pengaruh lebih baik daripada latihan konvensional yang dilakukan selama 6 minggu dengan 18 kali pertemuan. Hal ini dapat dibuktikan dengan adanya perbedaan peningkatan rata-rata (mean) yang didapatkan oleh masing-masing kelompok latihan. Kelompok latihan skipping \& side hop mengalami peningkatan (mean), yaitu sebesar 1,92 sedangkan kelompok latihan konvensional hanya mengalami peningkatan (mean) sebesar 0,28.

Sesuai dengan peningkatan keterampilan dribbling tersebut dapat disimpulkan bahwa latihan skipping dan side hop lebih baik dalam meningkatkan prestasi keterampilan dribbling jika dibandingkan dengan latihan konvensional. Kemudian berdasarkan hasil uji hipotesis analisis varians skor prestasi keterampilan dribbling antara kelompok latihan skipping dan side hop dengan kelompok latihan konvensional yang meng-gunakan uji $\mathrm{F}$, diperoleh $\mathrm{F}$ hitung sebesar 23,32 > dari $F$ tabel $\alpha 0.05=4,30$, sehingga dapat disimpulkan bahwa ada perbedaan pengaruh yang signifikan antara latihan skipping dan side hop dengan latihan konvensional. Hal tersebut dikarenakan untuk latihan konvensional tidak mendapatkan porsi latihan khusus untuk dapat meningkatkan keterampilan dribbling yang signifikan. Hal itu dikarenakan porsi latihan keterampilan dribbling dalam program latihan konvensional masih kurang.

Peningkatan ini diperoleh dari latihan atau penelitian pemberian perlakuan kepada 24 pemain U16-17 SSB PSDM selama enam minggu. Menurut Budiwanto (2012:16) "Latihan adalah proses melakukan kegiatan olahraga yang dilakukan berdasarkan program latihan yang disusun secara sistematis, bertujuan untuk meningkatkan kemampuan atlet dalam upaya mencapai prestasi yang semaksimal mungkin, terutama yang dilaksanakan untuk persiapan menghadapi suatu pertandingan".

Perlakuan yang telah diberikan membuat pemain SSB PSDM U16-17 dapat menguasai teknik keterampilan dribbling dengan baik. Pemain U16-17 SSB PSDM memiliki peningkatan dalam penguasaan bola dan melewati lawan dengan lebih baik yang ditunjukan pada saat game. Perlakuan bentuk latihan skipping dan side hop merupakan salah satu bentuk latihan dari pliometrik. Latihan skipping dan side hop merupakan salah satu bentuk latihan yang dapat meningkatkan daya ledak otot. Latihan skipping dan side hop dapat menghasilkan peningkatan kecepatan dan kelincahan. Menurut Redcliffe dan Farentinos (1985:2) "Latihan pliometrik telah digunakan sebagai metode latihan terutama untuk mengembangkan kekuatan, kecepatan dan power". Pemain dalam menggiring bola membutuhkan kecepatan dan kelincahan. Karena pemain dituntut mampu merubah arah menggiring bola sewaktu-sewaktu dan dapat menambah atau mengurangi kecepatan menggiring bola. Dalam menggiring bola menurut Mielke (2007:2) bahwa ada beberapa prinsip yang harus diperhatikan antara lain: 1) Menggiring bola dekat kaki, 2) Menggiring bola dengan sisi luar bagian depan kaki sementara pinggul tetap mengarah lurus ke depan, 3) Pemain berlatih mengubah arah menggiring bola, menambah atau mengurangi kecepatan dalam menggiring bola dan sewaktu-waktu menghentikan bola.

Keterampilan menggiring bola juga membutuhkan kondisi fisik yang baik karena dalam menggiring bola pemain harus dapat 
menambah atau mengurangi kecepatan dalam menggiring bola dengan sewaktuwaktu yang hal itu dapat menguras tenaga. Menurut Schuneman (2005:47) menjelaskan bahwa "memiliki skill menggiring bola memang penting, tapi pemain hendaknya tidak lupa bahwa menggiring bola sangat menguras tenaga dan seringkali memperlambat tempo permainan". pemain dalam menggiring bola harus memiliki kondisi yang baik untuk menunjang keterampilan dribbling tersebut. Kondisi fisik dapat ditingkatkan melalui latihan kecepatan dan kelincahan. Karena kecepatan dan kelincahan merupakan komponen dari kondisi fisik. Komponen-komponen kondisi fisik menurut Sajoto (1988:58-59) antara lain adalah kecepatan dan kelincahan. Kecepatan dan kelincahan dapat diperoleh melalui latihan pliometrik skipping dan side hop yang dapat menghasilkan peningkatan kecepatan dan kelincahan yang dibutuhkan dalam memiliki kondisi fisik yang baik untuk melakukan atau menguasai keterampilan dribbling yang baik.

\section{KESIMPULAN}

Berdasarkan pengujian hipotesis dan pembahasan dalam penelitian yang dilakukan maka diperoleh hasil peneliitian yang dapat disimpulkan bahwa: (1) Latihan skipping \& side hop berpengaruh terhadap peningkatan keterampilan dribbling pemain U16-U17 SSB PSDM Kabupaten Blitar. (2) Latihan Konvensional tidak berpengaruh lebih baik dari latihan skipping \& side hop terhadap peningkatan keterampilan dribbling pemain U16-U17 PSDM Kabupaten Blitar. (3) Latihan skipping \& side hop memberikan pengaruh lebih baik daripada latihan konvensional terhadap peningkatan keterampilan dribbling pemain U16-U17 SSB PSDM Kabupaten Blitar.

\section{SARAN}

Dengan memperhatikan hasil penelitian ini, maka dalam kesempatan ini penulis bermaksud ingin menyampaikan saransaran sehubungan dengan harapan peneliti agar nantinya penelitian ini memiliki kemanfaatan yang sangat berarti bagi banyak pihak, diantaranya: (1) Pelatih dapat menggunakan latihan skipping \& side hop sebagai bentuk latihan untuk meningkatkan keterampilan dribbling para pemain. (2) Dengan adanya penelitian tentang peningkatan keterampilan dribbling, para pemain memperoleh pengetahuan tentang bentukbentuk latihan keterampilan dribbling. Diharapkan dalam melakukan latihan selanjutnya para pemain SSB PSDM Kabupaten Blitar dapat meningkatkan keterampilan dribling dalam bermain sepakbola. (3) Dalam penelitian selanjutnya hendaknya melihat tentang penelitian sebelumnya sehingga dalam menentukan atau melakukan penelitian sesuai dengan rancangan yang diinginkan. Diharapkan dilakukan penelitian lebih lanjut mengenai penggunaan latihan skipping dan side hop yang lain untuk meningkatkan kemampuan siswa dalam bidang olahraga.

\section{DAFTAR PUSTAKA}

Aagaard, Marina. 2012. Rope Jumping Fitness. Denmark: E-BOOK.

Ali, M. \& Asrori, M. 2010. Psikologi Remaja Perkembangan Peserta Didik. Jakarta: PT Bumi Aksara.

Arikunto, Suharsimi. 2010. Prosedur Penelitian Suatu Pendekatan Praktik. Jakarta: PT RINEKA CIPTA

Batty, EC. 2004. Latihan Sepakbola Metode Baru Pertahanan. Bandung: Pionejaya.

Bompa, T.O. 1994. Theory and Methodology Of Training. $3^{\text {rd }}$ edition. Toronto, Ontorio: Kendal/Hunt Publishing Company.

Budiwanto, Setyo. 2012. Metodologi Latihan Olahraga. Malang: UM Press.

Chu, D. A. 1998. Jumping into Plyometrics. Champaign: Leisure Press.

Chu, D.A. 2006. Progressive Plyometrics for Kids. Monterey: Healthy Learning.

Corver, Wiel. 1985. Sepakbola Program Pembinaan Pemain Ideal. Jakarta: PT. Gramedia. 
Ririd Tsalis Mutaqin, Pengaruh Latihan Skipping dan Side Hop terhadap Keterampilan Dribbling Sepakbola Pada

Hadisasmita\& Syarifuddin, 1997. IImu Kepelatihan Dasar. Jakarta: Departemen Pendidikan dan Kebudayaan Direktorat Jendral Pendidikan Tinggi

Harsuki, 2003. Perkembangan Olahraga Terkini. Jakarta: PT. Raja Grafindo Persada

Hariyoko, 2010. Pengembangan Model Pembelajaran Keterampilan Dasar Sepakbola Peserta Ekstrakurikuler Sepakbola SMP Negeri di Kota Malang.

Harsono. 1988. Coaching \& Aspek-Aspek Psikologis dalam Coaching. Jakarta: Depdikbud..

Luxbacher, J.A. Tanpa tahun. Sepakbola. Terjemahan Agusta. 2004. Jakarta: PT. Raja Grafindo Persada.

Mielke,Danny. 2007. Dasar-Dasar Sepakbola. Jakarta:Pakar Raya.

Mutohir, T.C dan Maksum, Ali. 2007. Sport Development Index. Jakarta: PT. Indeks

Putera Ganesha. 2010. Villa 2000 Football Academy: Kutak-katik Latihan Sepakbola Usia Muda. Jakarta: PT Visi Gala 2000.

Radcliffe, J.C \& Farentinos, R.C. 1985. Plyometrics Explosive Power Training second ed. Champaign: Human Kinetics Publisher.

Rahayu Siti dkk, 2006. Psikologi Perkembangan. Yogyakarta: Gajah Mada UNIVERSITY PRESS

Sajoto, M. 1988. Pembinaan Kondisi Fisik Dalam Olahraga. Jakarta: DEPDIKBUD..

Scheuneman, Timo. 2005. Dasar Sepak Bola Modern untuk Pemain dan Pelatih. Malang: Penerbit DIOMA

Scheunemann, Timo S. 2012. Kurikulum \& Pedoman Dasar Sepakboa Indonesia. Malang: Dioma.

Solihin, A.O. dkk. 2010. Pendidikan Jasmani Olahraga dan Kesehatan. Jakarta: Pusat Perbukuan Kementrian Pendidikan Nasional.
Sugiyono.2013. Metode Penelitian Pendidikan Kualitatif dan Kualitatif, dan R\&D. Bandung. ALFABETA.

Sucipto, dkk. 2000. Sepakbola. Jakarta: Depdikbud.

Suharno, H.P. 1998. IImu Kepelatihan Olahraga. Yogyakarta: Ikip Yogyakarta.

Sukadiyanto. 2011. Pengantar Teori dan Metodologi Melatih Fisik. Bandung: CV. Lubuk Agung.

Sukmadinata, N.S 2013. Metode Penelitian Pendidikan. Bandung: PT. Remaja Rosdakarya

Winarno, M.E. 2013. Metodologi Penelitian dalam Pendidikan Jasmani. Malang: Fakultas IImu Pendidikan Universitas Negeri Malang. 